\title{
PEMERIKSAAN KADAR HAEMOGLOBIN PADA REMAJA PUTRI DI DESA SUGIHARJO KECAMATAN BATANG KUIS KABUPATEN DELI SERDANG
}

\author{
Suhartini $^{\text {1*, Juita } \text { Sari }^{2} \text {, Nila Hayati }}{ }^{3}$ \\ Universitas Haji Sumatera Utara ${ }^{1,2,3}$, \\ suhartini1902@gmail.com, sarijuita44@gmail.com,nilahayati28@gmail.com
}

\begin{abstract}
ABSTRAK
Anemia merupakan salah satu masalah kesehatan di seluruh dunia terutama negara berkembang, diperkirakan 30\% penduduk dunia menderita anemia dan banyak terjadi pada masyarakat terutama pada remaja dan ibu hamil. Kekurangan zat besi (Fe) dalam makanan sehari-hari dapat menimbulkan kekurangan darah yang dikenal sebagai anemia gizi besi (AGB). Strategi untuk mengatasi masalah anemia pada remaja putri adalah dengan perbaikan kebiasaan makan, fortifikasi makanan dan pemberian suplementasi Fe. Pengabdian ini sangat penting untuk dilakukan karena permasalahan mengenai anemia pada remaja putri di desa Sugiharjo masih merupakan topik yang menarik untuk dibahas.. Adapun tujuan pengabdian masyarakat ini adalah untuk mengidentifikasi kadar haemoglobin pada remaja putri di Desa Sugiharjo Kecamatan Batang Kuis Kabupaten Deli Serdang Tahun 2020.
\end{abstract}

Kata Kunci: Kadar Haemoglobin, Remaja

\begin{abstract}
Anemia is a health problem in all over the world, especially in developing countries, it is estimated that $30 \%$ of the world's population suffers from anemia and it occurs in many communities, especially adolescents and pregnant women. Lack of iron $(\mathrm{Fe})$ in the daily diet can cause a lack of blood known as iron nutritional anemia (AGB). Strategies to overcome the problem of anemia in adolescent girls are by improving their eating habits, fortification of food and giving iron supplementation. This service is very important to do because the problem of anemia in young women in Sugiharjo village is still an interesting topic to discuss. The purpose of this community service is to identify hemoglobin levels in young women in Sugiharjo Village, Batang Kuis District, Deli Serdang Regency in 2020.
\end{abstract}

Keyword : Hemoglobin Levels Adolescents

\section{PENDAHULUAN}

Anemia merupakan salah satu masalah kesehatan di seluruh dunia terutama negara berkembang, diperkirakan 30\% penduduk dunia menderita anemia dan banyak terjadi pada masyarakat terutama pada remaja dan ibu hamil. Anemia pada remaja putri sampai saat ini masih cukup tinggi, menurut World Health Organization (WHO). Prevalensi anemia dunia berkisar $40-88 \%$. \%, di Indonesia yaitu $21,7 \%$ dengan penderita anemia berumur 5-14 tahun sebesar 26,4\% dan 18,4\% penderita berumur 15-24 tahun (Ryandoko, 2017).

Anemia merupakan suatu keadaan dimana komponen di dalam darah yaitu hemoglobin $(\mathrm{Hb})$ dalam darah jumlahnya kurang dari kadar normal yaitu Hb kurang 12 gr/dl (Sayogo, 2006) Remaja putri memiliki risiko sepuluh kali lebih besar untuk menderita 
anemia dibandingkan dengan remaja putra. Anemia pada remaja dapat menyebabkan keterlambatan pertumbuhan fisik, gangguan perilaku serta emosional. Hal ini dapat mempengaruhi proses pertumbuhan dan perkembangan sel otak sehingga dapat menimbulkan daya tahan tubuh menurun, mudah lemas dan lapar, konsentrasi belajar terganggu, prestasi belajar menurun serta dapat mengakibatkan produktifitas kerja yang rendah (Wijianto, 2002).

Anemia gizi dipengaruhi beberapa faktor diantaranya jumlah asupan zat besi tidak cukup, penyerapan zat besi rendah, kebutuhan meningkat, kekurangan darah, pola makan tidak baik, status sosial ekonomi, penyakit infeksi, pengetahuan yang rendah tentang zat besi. Berdasarkan survei Profil kesehatan Provinsi Sumatera Utara tahun 2012 yang dilakukan di empat kabupaten, sebanyak 40,50 \% pekerja wanita menderita anemia. Data Survei Kesehatan Rumah Tangga (SKRT) tahun 2008 mengungkapkan prevalensi anemia defisiensi besi pada remaja putri (15-19 tahun) sebesar 26,5\% dan wanita usia subur sebesar $26,9 \%$.

Kekurangan zat besi (Fe) dalam makanan sehari-hari dapat menimbulkan kekurangan darah yang dikenal sebagai anemia gizi besi (AGB). Terdapat kesulitan dalam memenuhi kebutuhan $\mathrm{Fe}$ (zat besi) yaitu rendahnya tingkat penyerapan $\mathrm{Fe}$ dalam tubuh, terutama sumber Fe nabati yang hanya diserap 1-2\%, sumber Fe hewani mencapai 10-20\% (Adriani \& Wirjatmadi, 2012).

Strategi untuk mengatasi masalah anemia pada remaja putri adalah dengan perbaikan kebiasaan makan, fortifikasi makanan dan pemberian suplementasi Fe. Mengubah pola makan dan fortifikasi makanan merupakan strategi jangka panjang yang penting namun tidak dapat diharapkan dapat berhasil dengan cepat, cara lain dengan pemberian nutrisi dan melakukan pemeriksaan kadar haemoglobin secara rutin agar pencegahan anemia dapat diatasi. Pengabdian ini sangat penting untuk dilakukan karena permasalahan mengenai anemia pada remaja putri di desa Sugiharjo masih merupakan topik yang menarik untuk dibahas. Saat ini anemia merupakan salah satu masalah gizi utama di Indonesia khususnya anemia defisiensi besi, khususnya pada remaja. Adapun tujuan pengabdian masyarakat ini adalah untuk mengidentifikasi kadar haemoglobin pada remaja putri di Desa Sugiharjo Kecamatan Batang Kuis Kabupaten Deli Serdang Tahun 2020.

\section{METODE}

Data yang telah didapatkan dari tim survei dijadikan acuan dalam melaksanakan kegiatan. Kegiatan dilakukan dalam bentuk pemeriksaan kadar Haemoglobin dalam darah pada remaja putri dengan menggunakan metode Digital Test yang dilakukan tenaga analis dari RS Haji Medan.

\section{HASIL}

\section{Hasil Pelaksanaan Pemeriksaan Kadar Haemoglobin Pada Remaja}

Pelaksanaan dilakukan dengan beberapa susunan acara yang dihadiri oleh perangkat desa yang dihadiri oleh kepala desa dan dilanjutkan dengan pemeriksaan kadar Haemoglobin yang dilakukan kepada 60 orang remaja putri diambil dari 5 Dusun dan masing-masing dusun sebanyak 12 orang.

Pelaksanaan pengukuran kadar Haemoglobin berlangsung selama 5 jam, yang terdiri dari 5 sesi, sesi pertama dilakukan pemeriksaan Haemoglobin pada remaja yang 
tinggal di dusun I, sesi kedua di dudun II, sesi ke tiga di dusun III, sesi ke IV di dusun IV dan Sesi ke V di dusun V.
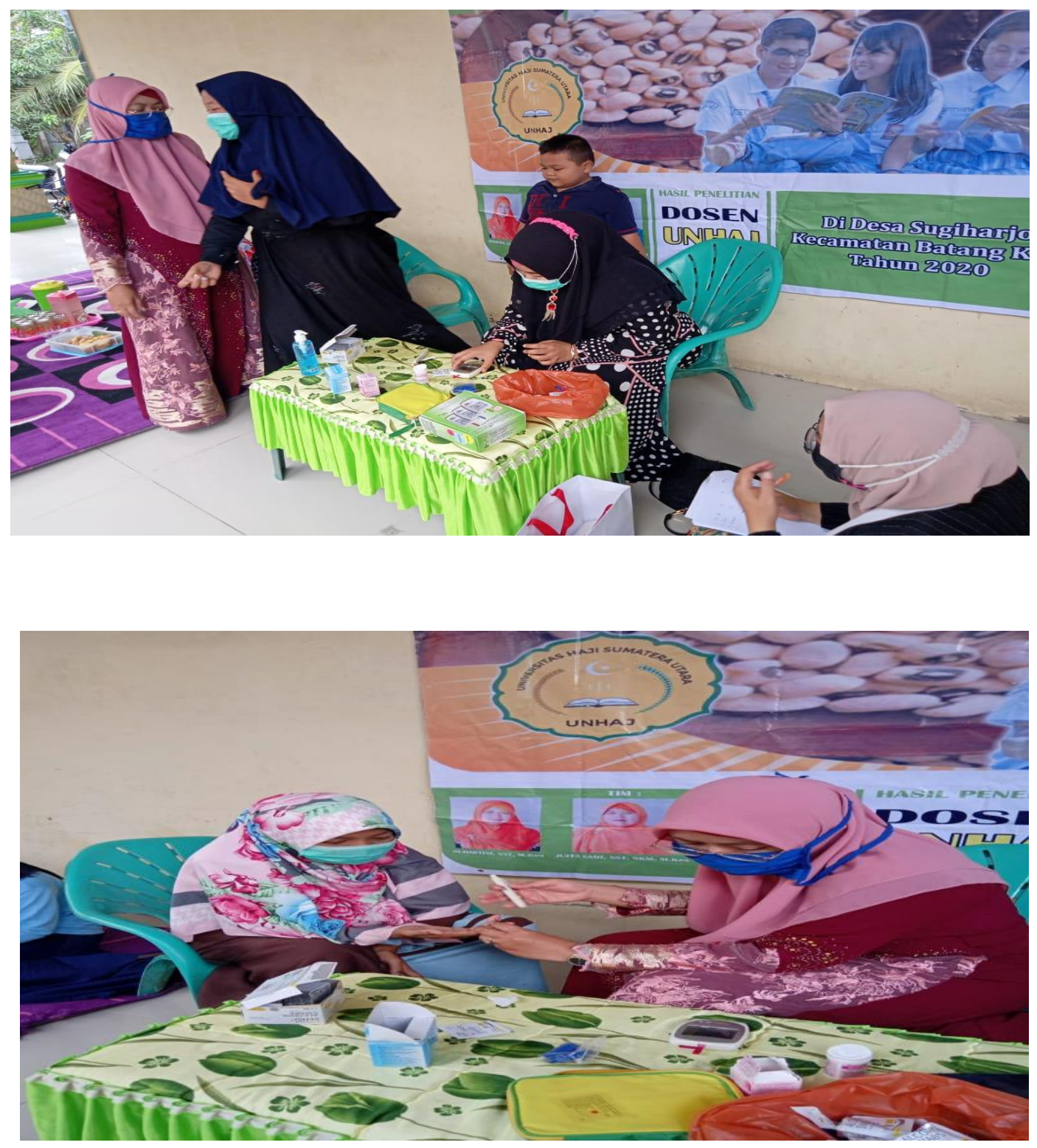

Gambar 1. Kegiatan Pemeriksaan Kadar Haemoglobin Pada Remaja 
Tabel 1. Data Demografi Remaja Putri

\begin{tabular}{|c|c|c|c|}
\hline No & Kategori & Jumlah & Persentase \\
\hline \multicolumn{4}{|c|}{ Umur } \\
\hline 1 & 15 tahun & 5 & 8.3 \\
\hline 2 & 16 tahun & 12 & 20.0 \\
\hline 3 & 17 tahun & 40 & 66.7 \\
\hline \multirow[t]{2}{*}{4} & 18 tahun & 3 & 5.0 \\
\hline & Total & 60 & 100 \\
\hline \multicolumn{4}{|c|}{ Pekerjaan Orang Tua } \\
\hline 1 & Petani & 53 & 88.3 \\
\hline 2 & Buruh Bangunan & 4 & 6.7 \\
\hline \multirow[t]{2}{*}{3} & Pedagang & 3 & 5.0 \\
\hline & Total & 60 & 100 \\
\hline \multicolumn{4}{|c|}{ Pendidikan Orang Tua } \\
\hline 1 & $\mathrm{SD}$ & 4 & 6.7 \\
\hline 2 & SMP & 23 & 38.3 \\
\hline 3 & SLTA & 33 & 55 \\
\hline \multicolumn{2}{|c|}{ Total } & 60 & 100 \\
\hline \multicolumn{4}{|c|}{ Riwayat Menstruasi } \\
\hline 1 & Tidak teratur & 3 & 5.0 \\
\hline \multirow[t]{2}{*}{2} & Teratur & 57 & 95.5 \\
\hline & Total & 60 & 100 \\
\hline
\end{tabular}

Berdasarkan Tabel 1 dapat diketahui bahwa distribusi frekuensi kategori umur dari 60 responden mayoritas berumur 17 tahun sebanyak 40 orang $(66.7 \%)$, berdasarkan pekerjaan orang tua mayoritas petani sebanyak 53 orang ( $88.3 \%$ ), pendidikan orang tua responden mayoritas SLTA sebanyak 33 orang ( $55 \%$ ). Berdasarkan riwayat menstruasi mayoritas mengalami menstruasi teratur sebanyak 57 orang $(57.5 \%)$.

Tabel 2 : Hasil Pemeriksaan Kadar Haemoglobin Pada Remaja

\begin{tabular}{lcccccc}
\hline \multicolumn{1}{c}{ Variabel } & Kategori & N & \% & Mean & Min & Max \\
\cline { 1 - 3 } Kadar & 10.0 & 45 & 75.0 & & & \\
Haemoglobin & 10.5 & 4 & 6.7 & & & \\
Pada Remaja & 11.0 & 9 & 15.0 & $\mathbf{1 0 . 2 4 2}$ & $\mathbf{1 0 . 0 0}$ & $\mathbf{1 2 . 0 0}$ \\
& 11.5 & 1 & 1.7 & & & \\
& 12.0 & 1 & 1.7 & & & \\
\cline { 1 - 4 } \multicolumn{1}{r}{ Total } & & $\mathbf{6 0}$ & $\mathbf{1 0 0}$ & & & \\
\hline
\end{tabular}

Sumber : Hasil Olah Data Pemeriksaan Kadar Haemoglobin Pada Remaja

Berdasarkan table 3 dapat diketahui bahwa distribusi frekuensi kadar HB pada remaja mayoritas $10 \mathrm{gr} / \mathrm{dl}$ sebanyak 45 orang ( $75.0 \%$ ). Mean (rata-rata) kadar haemoglobin adalah $10.242 \mathrm{gr} / \mathrm{dl}$. 


\section{PEMBAHASAN}

Dari pemeriksaan kadar haemoglobin yang sudah dilakukan pada remaja putri di Desa Sugihatjo Kecamatan Batang Kuis Kabupaten Deli Serdang didapatkan mayoritas kadar haemoglobin remaja putrid adalah $10 \mathrm{gr} / \mathrm{dl}$ sebanyak 45 orang ( $75.0 \%)$ dan remaja putri dalam kategori mengalami anemia. Pentingnya peningkatan kadar Haemogloin adalah untuk mencegah anemia. Anemia merupakan salah satu masalah kesehatan di seluruh dunia terutama negara berkembang yang diperkirakan $30 \%$ penduduk dunia menderita anemia. Anemia banyak terjadi pada masyarakat terutama pada remaja dan ibu hamil. Anemia pada remaja putri sampai saat ini masih cukup tinggi, menurut World Health Organization (WHO) (2013), prevalensi anemia dunia berkisar 40-88\%.Jumlah penduduk usia remaja (10-19 tahun) di Indonesia sebesar 26,2\% yang terdiri dari 50,9\% laki-laki dan 49,1\% perempuan.(World Health Organization, 2013).

Anemia merupakan suatu keadaan dimana komponen di dalam darah yaitu hemoglobin $(\mathrm{Hb})$ dalam darah jumlahnya kurang dari kadar normal. Remaja putri memiliki risiko sepuluh kali lebih besar untuk menderita anemia dibandingkan dengan remaja putra.Hal ini dikarenakan remaja putri mengalami mentruasi setiap bulannya dan sedang dalam masa pertumbuhan sehingga membutuhkan asupan zat besi yang lebih banyak. Penentuan anemia juga dapat dilakukan dengan mengukur hematokrit $(\mathrm{Ht})$ yang rata-rata setara dengan tiga kali kadar hemoglobin. Batas kadar $\mathrm{Hb}$ remaja putri untuk mendiagnosis anemia yaitu apabila kadar Hb kurang $12 \mathrm{gr} / \mathrm{dl}$. (Tarwoto dkk, 2012).

Anemia pada remaja dapat menyebabkan keterlambatan pertumbuhan fisik, gangguan perilaku serta emosional. Hal ini dapat mempengaruhi proses pertumbuhan dan perkembangan sel otak sehingga dapat menimbulkan daya tahan tubuh menurun, mudah lemas dan lapar, konsentrasi belajar terganggu, prestasi belajar menurun serta dapat mengakibatkan produktifitas kerja yang rendah (Sayogo, 2006).

Anemia gizi dipengaruhi oleh beberapa faktor diantaranya jumlah asupan zat besi tidak cukup, penyerapan zat besi rendah, kebutuhan meningkat, kekurangan darah, pola makan tidak baik, status sosial ekonomi, penyakit infeksi, pengetahuan yang rendah tentang zatbesi .Saat ini anemia merupakan salah satu masalah gizi utama di Indonesia khususnya anemia defisiensi besi, yang cukup menonjol pada anak-anak sekolah khususnya remaja (Wijianto, 2004)

Di Indonesia, prevalensi anemia masih cukup tinggi. Poltekkes Depkes Jakarta I (2010) menunjukkan bahwa penderita anemia pada remaja putri berjumlah $26,50 \%$. Menurut Riskesdas 2013 prevalensi anemia gizi besi pada remaja sebesar 22,7 \%. Menurut WHO di Indonesia prevalensi $26 \%$ untuk anak perempuan dan $11 \%$ untuk anak lakilaki.Menurut data hasil Riskesdas tahun 2013, prevalensi anemia di Indonesia yaitu 21,7\% dengan penderita anemia berumur 5-14 tahun sebesar 26,4\% dan 18,4\% penderita berumur 15-24 tahun (Kementrian Kesehatan Republik Indonesia, 2015) .

Kekurangan zat besi $(\mathrm{Fe})$ dalam makanan sehari-hari dapat menimbulkan kekurangan darah yang dikenal sebagai anemia gizi besi (AGB).Remaja putri lebih rawan terhadap anemia dibandingkan dengan laki-laki.Terdapat kesulitan dalam memenuhi kebutuhan $\mathrm{Fe}$ (zat besi) yaitu rendahnya tingkat penyerapan $\mathrm{Fe}$ dalam tubuh, terutama sumber Fe nabati yang hanya diserap 1-2\%.Sumber Fe hewani mencapai 10- 20\% (Aisyah, 2018).

Ada beberapa faktor yang dapat menyebabkan anemia antara lain adalah status gizi, menstruasi, dan sosial ekonomi Ryandoko (2017). Faktor utama penyebab anemia adalah asupan zat besi yang kurang. Sekitar dua per tiga zat besi dalam tubuh terdapat Wijianto (2004) dalam sel darah merah hemoglobin. Faktor lain yang berpengaruh terhadap kejadian anemia antara lain gaya hidup seperti merokok, minum minuman keras, 
kebiasaan sarapan pagi, sosial ekonomi dan demografi, pendidikan, jenis kelamin, umur dan wilayah. Hasil Riset Kesehatan Dasar (Riskesdas) Nasional tahun 2013 menunjukkan pravelensi anemia pada usia 5-14 tahun sebesar 26,4\%. Strategi untuk mengatasi status gizi dan masalah anemia pada remaja putri adalah dengan perbaikan kebiasaan makan, fortifikasi makanan dan pemberian suplementasi Fe. Mengubah pola makan dan fortifikasi makanan merupakan strategi jangka panjang yang penting namun tidak dapat diharapkan dapat berhasil dengan cepat, cara lain adalah dengan memberikan suplementai Fe melalui pemberian tablet tambah darah (TTD) dan pemberian penyuluhan tentang asupan zat gizi yang dapat menambah zat besi (Adriani \& Wirjatmadi, 2012).

Desa sugiharjo kecamatan Batang Kuis adalah desa yang kaya akan sumber makanan seperti padi dan sayur- sayuran dimana mayoritas latar belakang pekerjaan orang tua responden adalah petani. Hasil panen berupa padi, sayur -sayuran dan kacangkacangan. Latar belakang pendidikan orang tua mayoritas adalah SMA dimana pengetahuan orang tua dalam kategori baik dalam mempengaruhi pengetahuan mereka untuk mengolah sumber makanan yang bergizi dan memanfaatkan hasil panen dengan maksimal sebagai sumber bahan makanan yang baik dan bebas dari pengawet. Selain itu masyarakat desa sugiharjo juga rajin mengkonsumsi telur hasil ternak sendiri seperti telur ayam dan telur bebek sehingga untuk pemenuhan kebutuhan protein juga tercukupi. Protein juga berperan dalam pembentukan sel-sel darah merah. Dari 60 responden ada 3 responden yang mengalami menstruasi tidak teratur yaitu tidak setiap bulan akan tetapi setiap 2-3 bulan sekali, hal ini juga mempengaruhi peningkatan kadar HB responden dimana mereka tidak mengeluarkan darah menstruasi setiap bulan, sehingga pada saat dilakukan penelitian risiko untuk kekukarangan zat besi tidak terjadi. sehingga nutrisi kacang tolo yang di konsumsi juga akan terserap maksimal oleh tubuh.

\section{PENUTUP}

\section{Kesimpulan}

kadar HB pada remaja mayoritas $10 \mathrm{gr} / \mathrm{dl}$ sebanyak 45 orang $(75.0 \%), 10.5 \mathrm{gr} / \mathrm{dl} 4$ orang (6.7\%), $11 \mathrm{gr} / \mathrm{dl} 9$ orang (15\%), $11.5 \mathrm{gr} / \mathrm{dl} 1$ orang (1.7\%), $12 \mathrm{gr} / \mathrm{dl} 1$ orang (1.7\%), . Mean (rata-rata) kadar haemoglobin adalah $10.242 \mathrm{gr} / \mathrm{dl}$.

\section{Saran}

Kepada anak remaja putri, disarankan untuk lebih banyak mengkonsumsi makanan yang mengandung vitamin zat besi untuk meningkatan kadar $\mathrm{Hb}$. Untuk Desa bekerjasama dengan puskesmas setempat melakukan pemeriksaan Haemoglobin secara kontiniu.

Untuk Pendidikan Kebidanan dan tim medis lainnya melakukan penyuluhanpenyuluhan berkesinambungan terhadap masalah-masalah kesehatan.

\section{DAFTAR PUSTAKA}

Adriani dan Wirjatmadi.2012.Peranan Gizi dalam Siklus Kehidupan.Kencana. Jakarta. Wijianto. 2004. Dampak Suplementasi Tablet Tambah Darah (TTD) dan Faktor-faktor yang Berpengaruh terhadap Anemia Gizi Ibu Hamil di Kabupaten Banggai, Propinsi Sulawesi Tengah [skripsi]. Bogor : Departemen Gizi Masyarakat dan Sumberdaya Keluarga, Fakultas Pertanian, Institut Pertanian Bogor. 
World Health Organization (WHO). 2013. Worldwide Prevalency Of Anemia WHO Global database on Anemia. Geneva WHO Press

Wijianto. 2004. Dampak Suplementasi Tablet Tambah Darah (TTD) dan Faktor faktor yang Berpengaruh terhadap Anemia Gizi Ibu Hamil di Kabupaten Banggai, Propinsi Sulawesi Tengah [skripsi]. Bogor : Departemen Gizi Masyarakat dan Sumberdaya Keluarga, Fakultas Pertanian, Institut Pertanian Bogor.dd

Aisyah, 018, Faktor-Faktor yang Berhubungan dengan Kadar Hemoglobin pada Siswa SMP, The Southeast Asian Journal of Midwifery Vol. 4, No.2, October, 2018, p: 7681

Adriani dan Wirjatmadi.2012.Peranan Gizi dalam Siklus Kehidupan.Kencana. Jakarta. 